\title{
The Moderator Role of Environmental Interpretations in the Relationship between Planned Behavior Level and Environmental Awareness Perception of Hotel Employees
}

\author{
Özgür Yayla \\ Akdeniz University, Antalya, Turkey \\ Handan Özçelik Bozkurt \\ Sinop University, Sinop, Turkey \\ Emin Arslan \\ Tokat Gaziosmanpaşa University, Tokat, Turkey \\ Hakan Kendir \\ Tokat Gaziosmanpaşa University, Tokat, Turkey
}

Received: 29 July 2021. Revision received: 20 September 2021. Accepted: 4 October 2021

\begin{abstract}
Environmental problems, environmental awareness, and efforts to protect the environment are among the issues that concern the whole world and that need to be acted upon. Environmental concerns, which have come to the fore, especially in recent years, are closely related to the tourism sector. The main purpose of this research is to determine the moderator role of environmental interpretations in the relationship between planned behavior levels and environmental awareness perceptions of hotel employees. The sample of the research consists of 697 employees, who worked in five-star hotels in the Alanya region between the months of August and September 2020. As the data collection method in the research, the questionnaire technique has been preferred. As a result of the data obtained from the research, the Amos program was used to test the structural model. Respectively, these analyzes are reliability analysis, confirmatory factor analysis, discriminant analysis, and regression analysis. As a consequence of the regression analysis conducted within the context of the study, it has been determined that the level of attitude, which is considered to be one of the planned behavior factors of the employees in the hotel enterprises, has a positive and significant effect on their environmental awareness. In addition, it has been determined that environmental interpretations have a moderating role in the relationship between the attitude levels and environmental awareness of the employees, participated in the research.
\end{abstract}

Key Words: The theory of planned behavior, environmental awareness, environmental interpretations, hotel enterprises.

JEL Classification: L8, P21, P28.

Reference: Yayla, Ö., Özçelik Bozkurt, H., Arslan, E., Kendir, H. (2021). The Moderator Role of Environmental Interpretations in the Relationship between Planned Behavior Level and Environmental Awareness Perception of Hotel Employees. Journal of Tourism and Services, 23(12), 150-168. doi: 10.29036/jots.v12i23.287

\section{Introduction}

The problems related to the environment, environmental awareness, and environmental protection are some of the important issues that concern the whole world deeply and that should be 


\section{JOURNAL OF TOURISM AND SERVICES}

Issue 23, volume 12, ISSN 1804-5650 (Online)

www.jots.cz

collectively acted upon. The problems related to the environment and nature, which is considered to be a very sensitive situation in terms of the tourism sector, require public institutions and tourism enterprises to take some protective measures. Within the frame of the measures taken regarding the environmental problems in recent years, various environmental programs covering the tourism sector, particularly hotels, have been implemented. The main purpose of applying environmental programs by hotels is essentially based on reasons such as reducing costs, creating an environmentally friendly image perception, and protecting the environment. Therefore, hotel enterprises that make environmental plans, by possessing some of the eco-label certificates whose number is more than 50 worldwide, prefer to use these certificates in their corporate promotions (Chan, 2013). In this sense, when the environmentalist practices in Turkey are taken into consideration, the "green star" certificate given to hotel enterprises has come into prominence in recent years. The number of "green star certified" hotels, which are getting more and more widespread every year, has reached 457 in 2021 (KTB, 2021). A green and environmentalist image that protects nature is a very effective method in terms of raising environmental awareness and attracting customers to hotels. On the other hand, the practices aimed at protecting the environment bring about some financial burdens for hotel enterprises. That's why, hotel enterprises have to choose between environmental awareness and responsibility and their financial strength (Mercado \& Walker, 2012). At this point, the factors such as environmental policy, environmental awareness, and environmental interpretations of the hotel enterprises become rather influential.

It is observed that the studies in the literature on environmental awareness and environmental interpretations has focused on customer preferences, education, informing and behavioral activities (Maibach, 1993; McFarlanc \& Boxall, 2003; Ballantyne et al., 2008; Littledyke, 2008; Barron \& Prideaux, 2010; Cetin \& Nisanci, 2010; Sola, 2014; Xu et al., 2019; Uslu et al., 2020; Rustam et al., 2020; Marpa, 2020). The striking reality is that the majority of academic studies regarding environmental issues and covering hotel enterprises have been directed to the preferences of hotel customers. Nevertheless, in the context of environmental awareness and environmental interpretations of hotel employees, which are the most important components in terms of hotel enterprises, there are not enough studies in the tourism literature. On the other hand, all the employees of hotel enterprises who want to have a green and environmentalist image have to exhibit planned behaviors based on the environment. Therefore, the aforementioned situation is an important issue that needs to be academically researched and analyzed in the field of tourism.

The main purpose of the research is to determine the role of environmental interpretations in the relationship between hotel employees' planned behavior levels and environmental awareness perceptions. In this direction, after a general explanation in the first and second parts of the study, the theory of planned behavior, environmental awareness, and dimensions of environmental interpretations were evaluated conceptually. In addition, in the second part, the relevant literature dealing with the relationship between the concepts used in the research was examined. In the third part, the model of the research was created in line with the literature examined and the method followed in the research was determined within the scope of this model. In the fourth part of the study, data validity and reliability, and analysis of research hypotheses are presented. In the last section, the results obtained in line with the data obtained from the research are compared with the previous studies in the literature. In addition, within the scope of the research results, evaluations were made in terms of the tourism sector and literature and suggestions were developed.

\section{Literature review}

\subsection{The Theory of Planned Behavior}

Planned Behavior Theory was examined as an important theory used to explain what the individuals aim at with their behaviors in their jobs (Arnold et al., 2006) and it was also the subject of 


\section{JOURNAL OF TOURISM AND SERVICES}

Issue 23, volume 12, ISSN 1804-5650 (Online)

www.jots.cz

many other studies, as well (Evers \& Sieverding, 2015; Ye et al., 2017; Goh et al., 2017; Wang et al., 2018; Cera et al., 2020; Zdolsek Draksler \& Sirec, 2021).

In the related theory, the individual's intention to perform a certain behavior is taken as a central factor. When considered from this point, intentions include motivational factors that affect human behaviors and they are accepted as an indicator of how much they want to perform any kind of behavior (Ajzen, 1991). In addition, it has been emphasized that there is a social-cognitive model leading to the identification of intentions or motivations that play a key role in the emergence of a certain behavior in individuals (Tegova, 2010). According to the Planned Behavior Theory, while people behave in conformity with their perceptions and intentions of control over behavior, the intentions are affected by attitudes regarding behavior, subjective norms, and behavioral control perceptions (Ajzen, 2001).

In Planned Behavior Theory, there are a number of beliefs that guide human behavior. These are; the beliefs about the possible consequences or other characteristics of the behavior (behavioral beliefs; the individual has a positive or negative attitude towards his behavior), the beliefs about the normative expectations of other people (normative beliefs; arising as a result of pressure from the individual's social environment), and the beliefs about the presence of the factors that will increase or hinder the success of the behavior (control beliefs; increase perceived behavioral control in the individual) (Hrubes, Ajzen \& Daigle, 2001; Ajzen, 2002). The intention and behavior antecedents based on the Planned Behavior Model developed by Ajzen and Fishbein have been presented in Figure 1. However, the basic assumptions of the developed model have been listed as follows (Ajzen \& Fishbein, 2005).

Figure 1. Planned Behavior Model

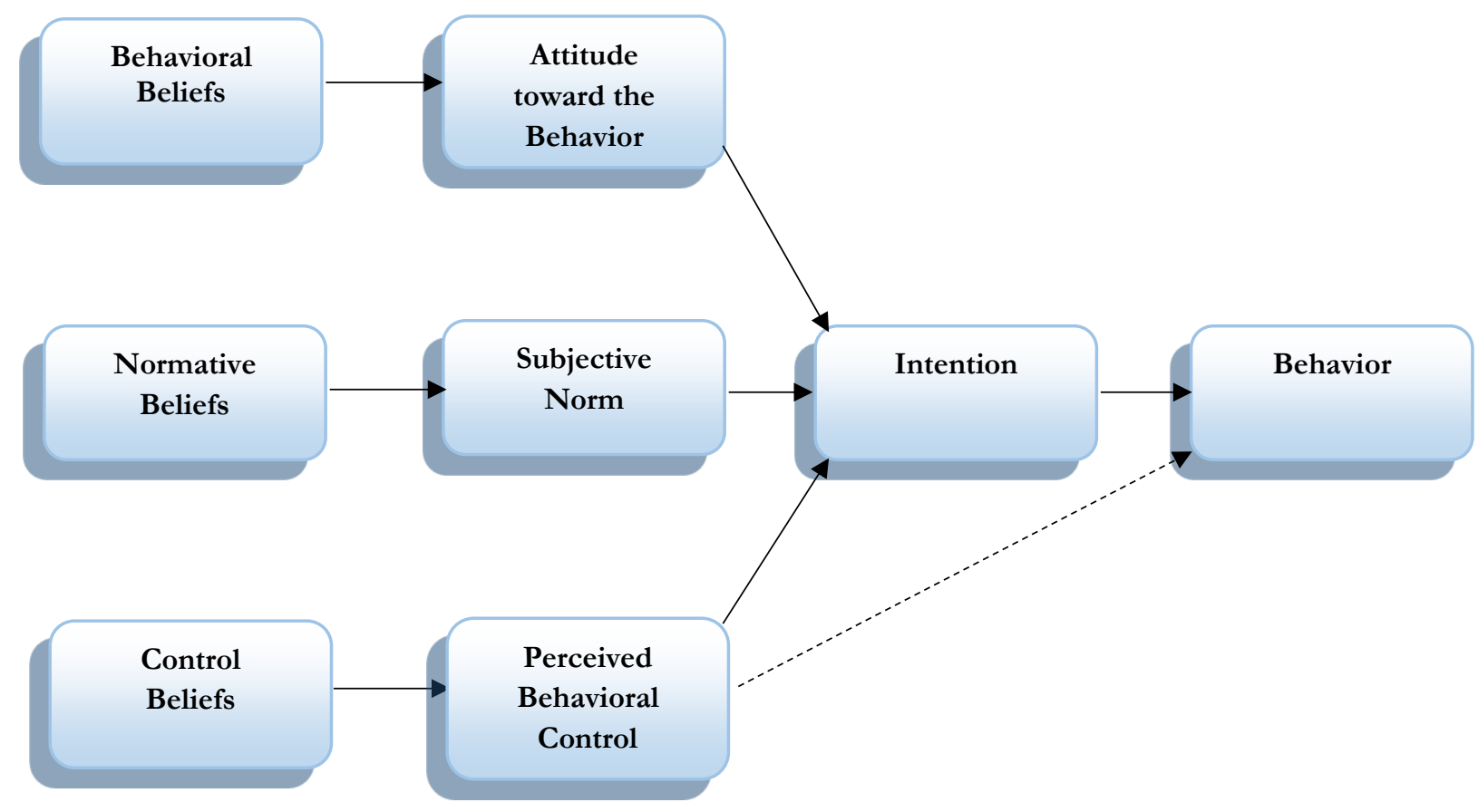

Source: (Ajzen, 1991; Ajzen \& Fishbein, 2005).

- Intention is considered to be the premise of actual behavior.

- Intention is determined by attitudes concerning behavior, subjective norms, and perceived behavioral controls.

- These determinants are functions of behavioral, normative and control beliefs, respectively. 


\section{JOURNAL OF TOURISM AND SERVICES}

Issue 23, volume 12, ISSN 1804-5650 (Online)

www.jots.cz

- Behavioral, normative, and control beliefs may change as a function of a wide variety of background factors.

Attitudes towards the Behavior: It expresses the positive or negative evaluations regarding the realization of the behavior. Therefore, the emotions revealed by these evaluations can cause positive or negative results in the individual (Fishbein, 2004). Besides, it has been stated that when the attitude towards the behavior is positive, the individual's intention to realize the behavior becomes stronger (Armitage \& Conner, 2001). In other words, the attitudes towards a certain behavior show their effects on behavior through intentions (Conner \& Armitage, 1998).

Subjective Norm: While behavioral beliefs lead to a particular attitude towards a behavior; normative beliefs produce perceived social pressure for a particular behavior (Evers \& Sieverding, 2015). Subjective norms, which are influenced by normative beliefs, signify social pressures that an individual perceives to perform or not to perform some certain environmental behaviors (Ajzen, 1991).

Perceived Behavioral Control: It refers to the individual's perception regarding whether it is difficult or easy to perform a certain environmental behavior. Besides, it is considered that perceived behavioral control may reflect the experiences of the individual and obstacles encountered (Ajzen, 1991). Nonetheless, it has been stated that control factors can be both internal (skill, ability, willpower, obligation) and external (time, opportunity, dependence on others) (Ajzen \& Madden, 1986; Sparks, Guthrie \& Shepherd, 1997).

Perceived behavioral control influences behavior in two ways. The first one of these is that it has various impacts on behavioral intention, and the other is that it can predict the behavior directly (Ajzen, 1991; Wang et al., 2018). The individuals who believe can gain control over their behaviors when they have the necessary skills and other resources to perform the behaviors and overcome the difficulties that are encountered. Nonetheless, those who believe may exhibit weaknesses in terms of individual willpower when they lack some of the necessary resources (Ajzen \& Fishbein, 2005).

In the light of this information, it is observed that Planned Behavior Theory has been used as a theory that is resorted to explain certain behaviors that individuals exhibit to achieve a goal they have adopted (Fishbein \& Ajzen, 1975). It is known that the behaviors exhibited by individuals are very valuable particularly in raising awareness about the environment, which is of vital importance for the survival of living things. It should not be ignored that the beliefs and the factors behind these beliefs are effective in the emergence of these behaviors.

\subsection{Environmental Awareness}

The continuity of human life on earth and the future of new generations are directly dependent on the structure of the ecosystem on earth. To accomplish social and economic development without harming biological assets, people from all strata, especially young people, should have environmental awareness (Du et al., 2018; Cortes et al., 2021). Informative, educational, stimulating, and behavioral activities that will increase environmental awareness in society are crucial for future generations in terms of sustainable development.

Individual behavior towards the environment can be positively or negatively affected by the individual's attitude towards the environment as well as by the moral and belief structure. Accordingly, individuals who have environmental awareness, are sensitive to the environment and have concerns about environmental degradation are expected to exhibit behaviors that are sensitive to the environment, care about and protect the environment in every aspect of their lives (Gadenne et al., (2009). Otherwise, it is possible for individuals to exhibit negative behaviors about environmental awareness and protection of the environment.

Environmental awareness and sensitivity can be determined by examining individuals' behavior regarding the issues such as environmental pollution and the preservation of natural balance. 


\section{JOURNAL OF TOURISM AND SERVICES}

Issue 23, volume 12, ISSN 1804-5650 (Online)

www.jots.cz

Environmental awareness is provided by increasing individuals' sensitivity about the environment, especially through education and information activities. When the literature on environmental awareness is analyzed, it is recognized that many studies (Littledyke, 2008; Barron \& Prideaux, 2010; Cetin \& Nisanci, 2010; Sola, 2014; Marpa, 2020) emphasize the importance of education and providing necessary information. Additionally, studies that deal with concepts such as marketing, consumer preferences, and experiences within the framework of environmental awareness (Maibach, 1993; Ballantyne et al., 2008; Xu et al., 2019; Rustam et al., 2020) also draw attention.

Environmental awareness is a concept that has been studied academically in the tourism literature. Studies on the hotel industry focus on some issues which are sustainable development, the performance of environmental practices, (Stabler \& Goodall, 1997) environmental sustainability, and hotel customers' demand for green practices (Bohdanowicz, 2006). Studies on touristic natural and ecological park areas emphasize the subjects of visitor behavior, sustainable tourism, the protection of rural areas (Ballantyne et al., 2008; Lima, 2013), and creating environmental awareness of rural people (Du et al., 2018). On the other hand, in a different study on tourism education, determining the environmental awareness of students who are receiving tourism education was the focal point of the research. (Barron \& Prideaux, 2010).These studies show that the concepts of tourism and environmental awareness are frequently associated in the literature.

Considering both the tourism literature and the general literature on environmental awareness, it seems possible to associate the concepts such as planned behavior theory and environmental interpretations, which are the subject of this study, with environmental awareness. Therefore, it can be said that the relevant literature is compatible with the aim of the study. Within the scope of these explanations, the following hypotheses have been developed.

$\mathbf{H}_{1}$ : The attitude dimension, one of the planned behavior factors, has an effect on environmental awareness.

$\mathbf{H}_{2}$ : The subjective norm dimension, one of the planned behavior factors, has an effect on environmental awareness.

$\mathbf{H}_{3}$ : The control dimension, one of the planned behavior factors, has an effect on environmental awareness.

\subsection{Environmental Interpretations}

The individual is intertwined with the environment beginning from the time $\mathrm{s} / \mathrm{he}$ is born (Margerum \& Born, 1995). Environmental behaviors develop and may change over time, depending on external factors such as the policies of the society in practice or culture (Gavurova et al. 2021). In other words, general beliefs and values in society affect people's attitudes or behaviors towards the environment (Schultz, \& Zelezny, 1999). On the other hand, environmental interpretations can be determinative in the formation of environmental behaviors. Environmental interpretations are explained in four basic groups as educational, encouraging, punitive, and persuasive. These groups are found and managed in the daily usage areas of individuals (Wang, et al. 2018). Environmental information and warnings have an important place in developing the relationship between environmental attitude and awareness in order to support people's beliefs, value judgments and behaviors that develop accordingly (McFarlanc \& Boxall, 2003).

The use and size of environmental stimuli in designated places is very important in terms of perception of the stimulus by the target audience. (Wohlwill, 1974). Due to the negative effects of the tourism industry on the environment (Azam et al., 2018; Shafieisabet \& Haratifad, 2020), the importance of environmental interpretations in destinations or around the business is increasing. In touristic destinations, the signs that increase awareness about the present environment reveal the role of environmental interpretations. At the same time, the rules set by businesses, destination management 


\section{JOURNAL OF TOURISM AND SERVICES}

Issue 23, volume 12, ISSN 1804-5650 (Online)

www.jots.cz

organizations, or policymakers can be perceived as environmental interpretations by individuals, and environmental behaviors can develop positively. The current literature points out that, through the adopted environmental management systems, the environmental performances of the managerial staff and employees have increased by obliging certain rules to be complied with (Boiral et al., 2018; Yin \& Schmeidler, 2009; Qi et al., 2012). On the other hand, the regulatory role of environmental interpretations in the effect of attitude, subjective norm, and perceived behavioral control on environmental awareness, which is examined within the context of planned behavior theory, remains unclear in the literature. In this sense, the research hypothesis has been developed as follows:

$\mathbf{H}_{4}$ : Environmental interpretations have a moderator role in the effect of the attitude dimension, which is one of the planned behavior factors, on environmental awareness.

$\mathbf{H}_{5}$ : Environmental interpretations have a moderator role in the effect of the subjective norm dimension, which is one of the planned behavior factors, on environmental awareness.

$\mathbf{H}_{6}$ : Environmental interpretations have a moderator role in the effect of the control dimension, which is one of the planned behavior factors, on environmental awareness.

\section{Methodology}

\subsection{Research instrument}

This research was carried out in Alanya sample in order to determine the moderator role of environmental interpretations in the relationship between the planned behavior levels of hotel employees and their perception of environmental awareness. The scales utilized for the purpose of the research have been prepared as a consequence of a comprehensive literature review. A total of 10 statements, consisting of the sub-dimensions of attitude (4 statements), subjective norms ( 3 statements), and perceived behavioral control (3 statements), which were determined in terms of the theory of planned behavior have been adapted based on the previous studies in the literature (Ajzen, 1991; Brown et al. 2010; Miller et al. 2015; Wang et al. 2018). A 4-statement scale developed by Ryan \& Spash (2008) was used to measure environmental awareness in order to measure environmental awareness, which has a dependent variable, 4 expressions belonging to the environmental interpretations determined within the scope of the study as the moderator variable have been adapted from the study of Wang et al. (2018). A total of 18 statements were applied to five-star hotel employees using a 5-point Likert (1=strongly disagree; $5=$ strongly agree).

\subsection{Sampling and data collection}

Alanya is one of the most important tourism centers in Turkey. As a matter of fact, according to the data of 2019, 4.4 million tourists visited Alanya (Ministry of Culture and Tourism, 2019a). As a natural consequence of this situation, the number of hotel enterprises in Alanya destination and personnel working these enterprises is quite high. There are a total of 82 five-star hotels in Alanya, 29 of which are green-starred (Ministry of Culture and Tourism, 2020). Due to such reasons, the employees working in five-star hotels in Alanya have been designated as the population of the research. The data of the research were obtained from employees who worked in five-star hotels in Alanya region between the months of August and September, 2020. A total of 750 employees were surveyed using the convenience sampling method and the analyses were conducted on 697 surveys by removing the questionnaires containing incorrect and missing data.

\subsection{Pilot test}




\section{JOURNAL OF TOURISM AND SERVICES}

Issue 23, volume 12, ISSN 1804-5650 (Online)

www.jots.cz

Before the research questionnaire was collected, a pilot test was applied to 40 people. As a result of the data obtained from the pilot test, the validity and reliability results of the questionnaire were accepted to be appropriate (Hair et al., 2005). At the same time, as a result of the pilot data, the clarity of the questions was measured and it was decided that the style and clarity of all questions were ensured, and the actual data collection stage was started.

\subsection{Data analysis}

The obtained data were transferred to the SPSS package program and the analysis of the data was carried out via the AMOS software. A two-step approach (Anderson \& Gerbing, 1988) was adopted for the structural equation model, whereby the measurement model and the structural model are evaluated separately. The structural model is tested only if the measurement model has acceptable fit indices. Besides overall fit values, convergent validity, composite reliability, and discriminant validity values were examined for the measurement model. For the structural model, overall fit values $\chi^{2}, \chi^{2} / \mathrm{df}$, comparative fit indices CFI, IFI (incremental fit index), RMSEA (root mean square error of approximation), and absolute fit indices GFI (goodness of fit index) and AGFI (adjusted goodness of fit index) values were tested.

In order to analyze the moderator effects, Process v3.5 plugin developed by Andrew F. Hayes was used in SPSS program. The reason why this method is preferred is that the program, which has a simple interface, calculates a confidence interval within its own algorithm and this value interval is determined by the program. In this respect, the program provides convenience to researchers in terms of explainability and use (Preacher \& Hayes, 2008). Model 1 was preferred for the moderator effect on the created structural model (Hayes, 2013). It was calculated according to the confidence intervals obtained by the Bootstrap (5000 people) method whether there were moderator effects or not.

\section{Findings}

\subsection{Demographic findings}

When the demographic characteristics of the people participating in the research have been analyzed, it is observed that $59 \%$ of them are male $(n=411)$ and $41 \%(n=286)$ are female. Besides, as for the age range of the participants, $18 \%$ of the employees are between 18-25 ( $\mathrm{n}=128), 33 \%$ are between 25-34 $(n=233), 31 \%$ are between $35-44(n=219), 16 \%$ are between $45-54(n=108)$ and $1 \%$ are 55 years old and over $(\mathrm{n}=9)$. When they are evaluated in terms of their marital status, the data obtained reveal that $58 \%$ are married $(n=403)$ and $42 \%$ are single $(n=294)$. While $23 \%$ of the employees are primary school graduates $(n=158), 39 \%$ have secondary school degree $(n=273), 17 \%$ have associate degree $(n=116), 20 \%$ have undergraduate degree $(n=139)$ and $2 \%$ have postgraduate degree $(n=11)$. As for their work experience, it has been determined that $2 \%(n=14)$ of the employees have one year or less sector experience, 38\% $(n=263)$ have between $1-5$ years, 33\% $(n=232)$ have between $6-10$ years and $27 \%$ $(n=188)$ have 11 years or more sectoral experience. While $14 \%(n=94)$ of the research data was obtained from service and bar personnel, 19\% $(n=133)$ from kitchen department, 16\% ( $\mathrm{n}=108)$ from housekeeping department, $22 \%(\mathrm{n}=150)$ from front Office department and 30\% $(\mathrm{n}=212)$ from human resources department employees. Moreover, while $55 \%(n=382)$ of the employees work in the hotels that have a green star, the hotels in which the remaining $45 \%(n=315)$ work do not have a green star.

\subsection{Model validity}

The validity and reliability of the research model were determined before testing the structural model. Confirmatory Factor Analysis (CFA) was applied to the variables in order to define the relevant 


\section{JOURNAL OF TOURISM AND SERVICES}

Issue 23, volume 12, ISSN 1804-5650 (Online)

www.jots.cz

values and the results have been presented in Table 1. According to the analysis results, it can be affirmed that the data belonging to the variables are in a decent accordance with each other $(\chi 2=433.389, \mathrm{df}=$ $123, \mathrm{p}<0.01 \chi^{2} / \mathrm{df}=3.523, \mathrm{GFI}=0.935, \mathrm{AGFI}=0.909, \mathrm{RMSEA}=0.060$, CFI $\left.=0.959, \mathrm{NFI}=0.943\right)$. $\chi 2 /$ df score's being below 5 presents an acceptable concordance (Marsh \& Hocevar, 1985). CFI, GFI, AGFI, NFI values' being greater than 0.90 indicates a good concordance (Tabachnick \& Fidell, 2007; Byrne, 2016). As a result of the RMSA value being less than 0.80, it was decided that the model concordance has been achieved (Hu \& Bentler, 1999). On the other hand, the minimum value regarding the factor loads was defined as 0.568 and it can be expressed that all 18 items included in the scale are statistically significant $(\mathrm{p}<0.001)$. The alpha values for each construct of the scales are between 0.736 and 0.921. This result shows the reliability of the scale (Nunnally, 1978). In addition, the minimum composite reliability (CR) value's being equal to 0.77 indicates that structural reliability has been ensured (Bagozzi \& Yi, 1988). Within the context of convergent validity, average variance (AVE) values were analyzed and it has been observed that all of the values are 0,50 and above. In the light of these results, it can be stated that the convergent validity has been provided by the research model (Malhotra \& Dash, 2011).

Table 1. Structural Equation Model (SEM) Results of the research model

\begin{tabular}{|c|c|c|c|c|c|c|}
\hline Factors / Items & $\begin{array}{l}\text { Standard } \\
\text { loadings }\end{array}$ & t-value & $R^{2}$ & CR & AVE & CA \\
\hline Factor $A T T:$ Attitude & & & & 0.86 & 0.62 & 0.856 \\
\hline $\begin{array}{l}\text { "I think protecting the environment of the scenic } \\
\text { spot is wise." }\end{array}$ & 0.61 & & 0.37 & & & \\
\hline $\begin{array}{l}\text { "I think protecting the environment of the scenic } \\
\text { spot is good." }\end{array}$ & 0.91 & $18, .67^{*}$ & 0.83 & & & \\
\hline $\begin{array}{l}\text { "I think protecting the environment of the scenic } \\
\text { spot is worthwhile." }\end{array}$ & 0.95 & $18.60^{*}$ & 0.94 & & & \\
\hline $\begin{array}{l}\text { "I think protecting the environment of the scenic } \\
\text { spot is beneficial." }\end{array}$ & 0.63 & $15.01 *$ & 0.39 & & & \\
\hline Factor $S N$ : Subjective norm & & & & 0.78 & 0.54 & 0.736 \\
\hline $\begin{array}{l}\text { "Most people who are important to me think I } \\
\text { should protect the environment of the scenic } \\
\text { spot." }\end{array}$ & 0.79 & & 0.62 & & & \\
\hline $\begin{array}{l}\text { "People whose opinions I value would want me } \\
\text { to protect the environment of the scenic spot." }\end{array}$ & 0.84 & $17.03^{*}$ & 0.70 & & & \\
\hline $\begin{array}{l}\text { "People I am familiar with would protect the } \\
\text { environment of the scenic spot." }\end{array}$ & 0.56 & $13.41 *$ & 0.31 & & & \\
\hline Factor PBC: Perceived behavioral control & & & & 0.77 & 0.53 & 0.764 \\
\hline $\begin{array}{l}\text { "I am confident that if I want, I can protect the } \\
\text { environment of the scenic spot." }\end{array}$ & 0.70 & & 0.50 & & & \\
\hline $\begin{array}{l}\text { "Whether or not I protect the environment of the } \\
\text { scenic spot is completely up to me." }\end{array}$ & 0.75 & $14.90^{*}$ & 0.57 & & & \\
\hline $\begin{array}{l}\text { "It is easy for me to protect the environment of } \\
\text { the scenic spot." }\end{array}$ & 0.72 & $14.73^{*}$ & 0.52 & & & \\
\hline Factor EI: Environmental Interpretations & & & & 0.91 & 0.72 & 0.921 \\
\hline $\begin{array}{l}\text { "Environmental warning signages in the scenic } \\
\text { spot make me regulate my environmental } \\
\text { behaviors consciously." }\end{array}$ & 0.57 & & 0.32 & & & \\
\hline
\end{tabular}




\section{JOURNAL OF TOURISM AND SERVICES}

Issue 23, volume 12, ISSN 1804-5650 (Online)

www.jots.cz

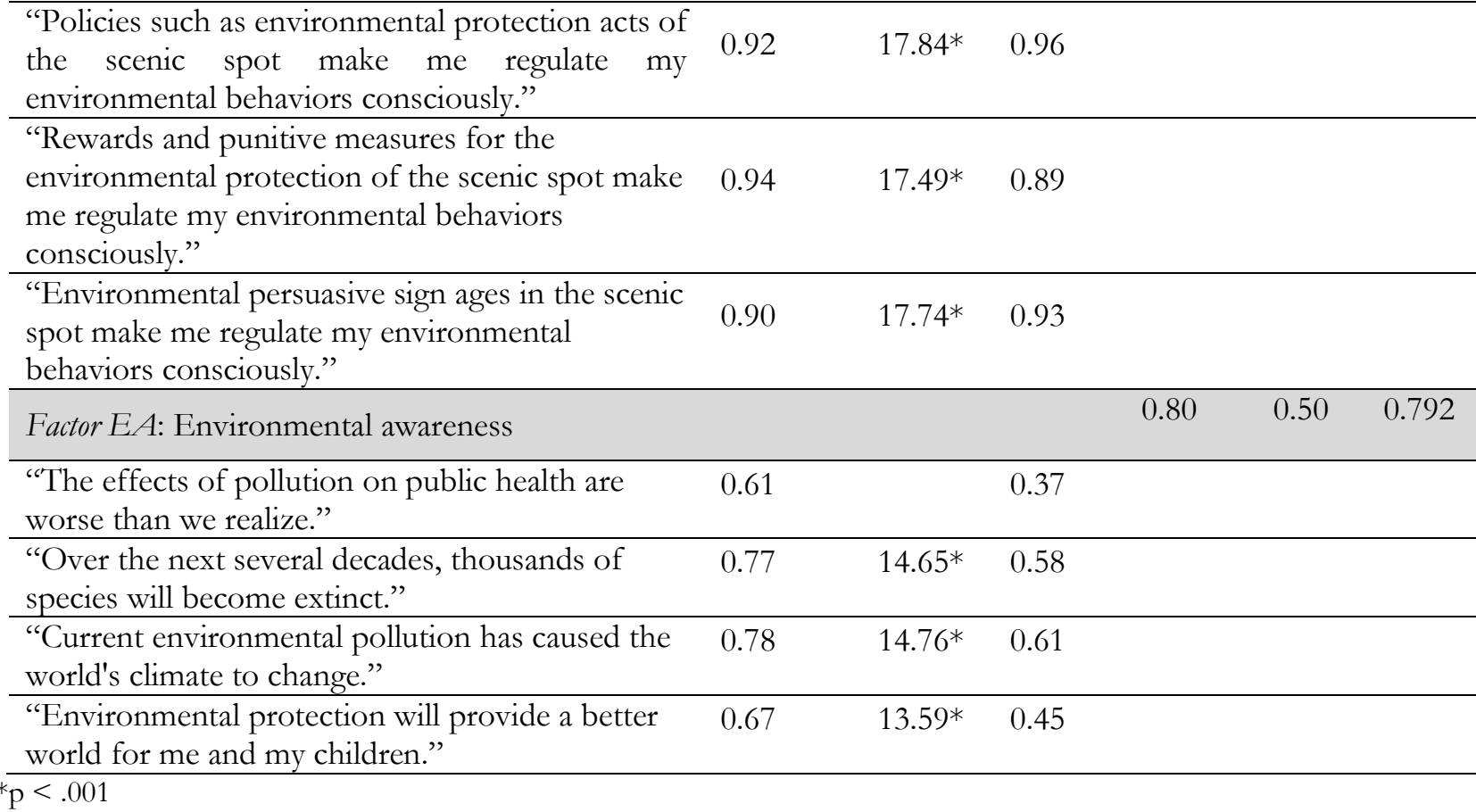

Source: own research

The discriminant validity of the model has been presented in Table 2 . When the results of the table have been evaluated, it is seen that the square root of the AVE value of each structure is higher than all the values in the related row. In addition, since each Maximum squared variance (MSV) and Average shared square variance (ASV) value of the structure is lower than the AVE value, it has been decided that the discriminant validity has been provided (Fornell \& Larcker, 1981).

Table 2. Result of Discriminant Validity

\begin{tabular}{lccccccc}
\hline Factor & MSV & ASV & $\mathbf{1}$ & $\mathbf{2}$ & $\mathbf{3}$ & $\mathbf{4}$ & $\mathbf{5}$ \\
\hline 1.ATT & 0.092 & 0.062 & $0.790^{\mathrm{a}}$ & & & & \\
\hline 2.SN & 0.184 & 0.071 & 0.303 & $0.736^{\mathrm{a}}$ & & & \\
\hline 3.PBC & 0.184 & 0.053 & -0.047 & 0.429 & $0.726^{\mathrm{a}}$ & & \\
\hline 4.EI & 0.036 & 0.016 & 0.107 & 0.101 & 0.095 & $0.846^{\mathrm{a}}$ & \\
\hline 5.EA & 0.144 & 0.050 & 0.380 & 0.005 & -0.141 & 0.192 & $0.710^{\mathrm{a}}$ \\
\hline
\end{tabular}

aThe square root of the AVE

Source: own research

\subsection{Hypothesis tests}

In the research, Structural Equation Model (SEM) was used with the purpose of testing the determined hypotheses. When the concordance values of the structural model have been examined, it is understood that the research data are considered to be within acceptable limits $(\chi 2=352365, \mathrm{df}=71$, $\mathrm{p}<0.01, \chi 2 / \mathrm{df}=4.973, \mathrm{RMSEA}=0.075, \mathrm{CFI}=0.932$, GFI=0.927; AGFI=0.893; $\mathrm{IFI}=0.932)$. Although the p value is expected to be insignificant for goodness of fit (Fan et al., 2016), the value is sensitive to sample size. In the literature, there are studies that accept the data set as appropriate despite the significance of the p value if all other values are appropriate (Mackinnon et al., 1999; Shadfar \& Malekmohammadi, 2013; Jono \& Ardila, 2018; Buyucek et al., 2019). The path analysis related to the model has been shown 
in Figure 2. When the results have been examined, within the context of planned behavior theory, while the attitude dimension has a strong positive impact on environmental awareness $(\beta=.405, t=7.565$, $\mathrm{p}<0.001$ ), no statistically significant effect has been determined on environmental awareness in the dimensions of subjective norm and perceived behavioral control. In the light of these results, while the $\mathrm{H} 1$ hypothesis has been accepted, the H2, H3, H5 and $\mathrm{H} 6$ hypotheses have been rejected.

Figure 2: Hypothesis Tests

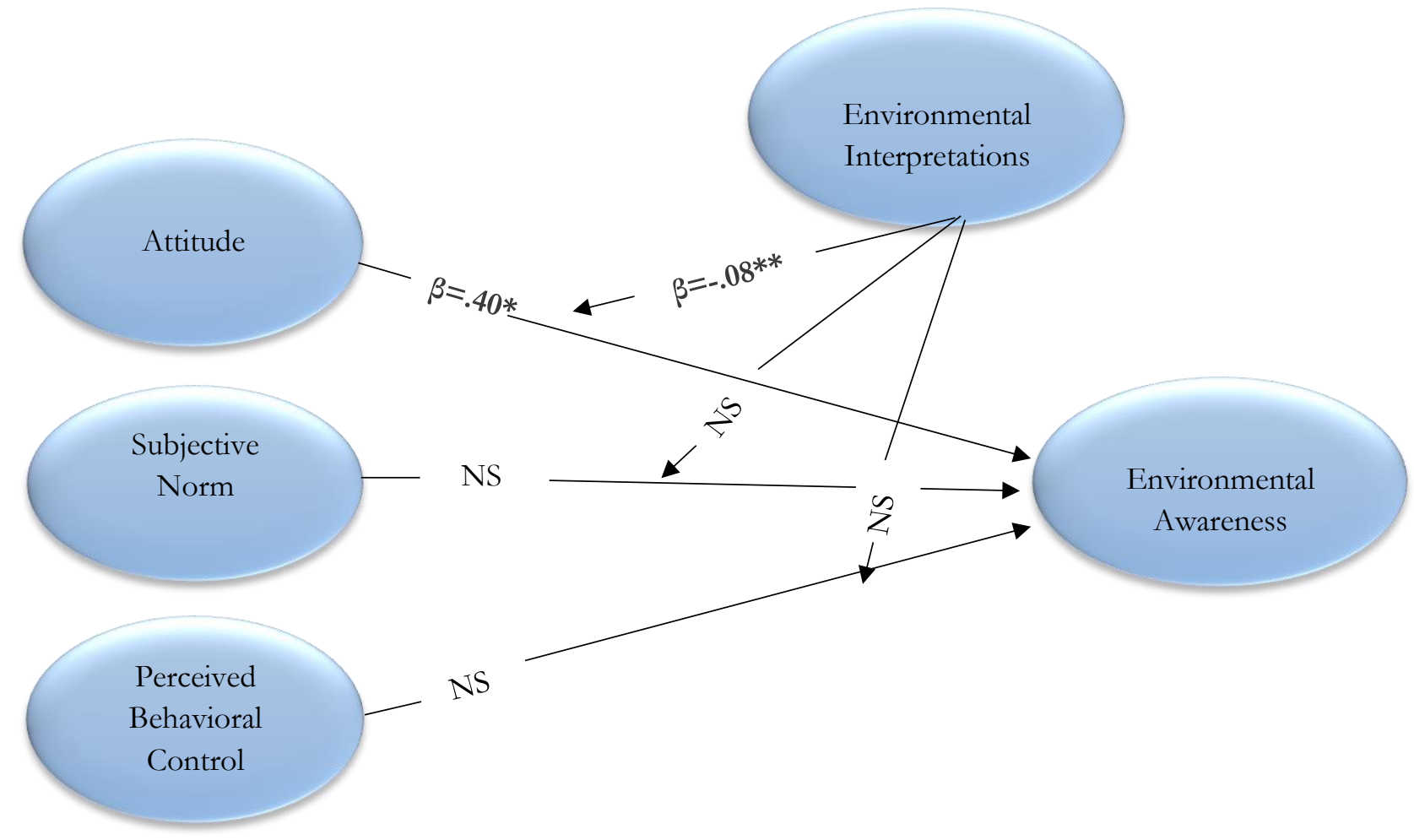

${ }^{*}$ p $<0.001{ }^{* *}$ p $<0.05$ NS: No Significant

Source: own research

\subsection{Moderation effect}

In order to test the moderator role of environmental interpretations in the effect of attitude on environmental awareness, regression analysis based on the bootstrap method has been performed. It is suggested that more reliable results are obtained with the Bootstrap method than the traditional method of Baron and Kenny (1986) (Hayes, 2013). Analyzes have been made by using "Model 1" in the Process Macro model developed by Hayes (2013). In the analysis, 5000 re-sampling options have been preferred with the bootstrap technique. Results of the moderator effect have been given in Table 3.

Table 3. Moderated Effect Result

\begin{tabular}{|c|c|c|c|}
\hline Moderating Effect: & \multicolumn{3}{|c|}{ Environmental awareness } \\
\hline & $\beta$ & Confid & $\overline{\text { terval }}$ \\
\hline Hypothesis 4 & & Min & Max \\
\hline Attitude $(X)$ & $0.67 *$ & 0.391 & 0.955 \\
\hline
\end{tabular}


Environmental interpretations (W)

$\mathrm{X} . \mathrm{W}$ (Interaction)

$0.48 * *$

0.172

0.794

$\mathrm{R}^{2}$

Environmental

$-0.08^{* *}$

$-0.153$

$-0.020$ interpretations

\begin{tabular}{rlllll}
\hline Low & $0.23^{*}$ & 0.02 & 11.77 & 0.277 & 0.389 \\
\hline Moderate & $0.30^{*}$ & 0.02 & 11.19 & 0.251 & 0.358 \\
\hline High & $0.33^{*}$ & 0.03 & 6.12 & 0.163 & 0.316 \\
\hline
\end{tabular}

$*_{\mathrm{p}}<0.001 * *_{\mathrm{p}}<0.05$

Source: own research

Graph 1. Graphical Notation of the Moderator Effect of Environmental Interpretations

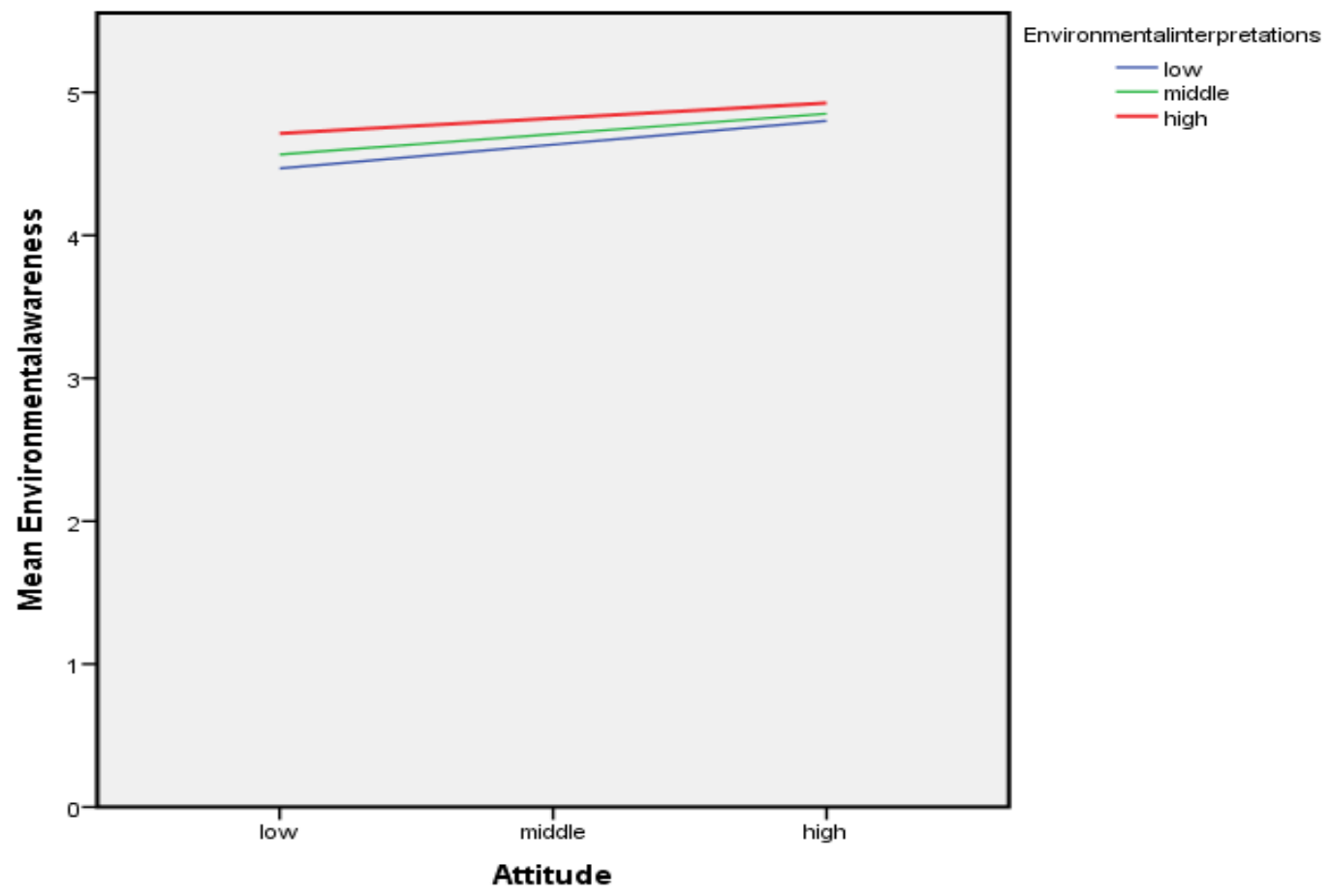

Source: own research

According to the results in Table 3, it has been determined that the fourth hypothesis of the study, attitude, environmental interpretations, and the interactional term had a significant effect on the outcome variable, environmental awareness. The significant $\beta$ value of the interactional effect variable, which indicates whether there is a regulatory effect or not, indicates that the environmental interpretations variable has a regulatory effect $(\beta=-0.08,95 \%$ CI $[-0.153,-0.020], \mathrm{p}<0.05)$. Therefore, the $\mathrm{H} 4$ hypothesis has been accepted. With the results, it has been seen that all the estimation variables included in the regression analysis explained approximately $22 \%$ of the change in environmental awareness. When the details of the regulatory effect have been examined, it has been observed that the effect of the attitude on environmental awareness increased with the increase in environmental interpretations. This relevant effect has been shown in Graphic 1. 


\section{Discussion}

As a result of the literature review, no study has been found that examines the theory of planned behavior, environmental awareness, and environmental interpretations together. In this respect, the findings obtained from this study are of a quality that will contribute to the relevant literature and lead. In addition, it is thought by the authors that this situation makes the study important and unique in terms of literature.

According to the findings and results obtained within the scope of the study, a positive and significant relationship was determined between the level of attitude, which is one of the planned behavior factors, and the environmental awareness variable. However, no significant relationship was found between other planned behavior factor levels and environmental awareness. This finding reveals the possibility of participants to develop attitudes and raise awareness on environmental issues. The result obtained is similar to the results of the environmental awareness research conducted with teacher participants by Adejoke et al. (2014). However, this is different from the results of the research conducted by Arshad et al. (2021) on environmental awareness and behavior of university students. In the aforementioned study, a negative relationship was found between students' attitude levels, environmental awareness, and environmental behaviors. This situation can be explained by the fact that the sample group in the research is different from the other research. In addition, it can be said that employees can develop more positive attitudes than students due to the concern that environmental damage may affect their future business life.

\section{Conclusion}

The sample of this research, which aims to determine the role of environmental stimuli in the relationship between the planned behavior levels of employees in hotel enterprises and their perceptions of environmental awareness, consists of 697 personnel working in five-star hotel enterprises in Alanya. It is very important for sustainable tourism that hotel employees, who are one of the most basic components of the tourism sector, exhibit positive awareness of environmental issues. In this respect, obtaining data that can be measured in terms of environmental awareness and environmental interpretations from hotel employees will shed light on the sector and the literature.

The moderating role of environmental interpretations in the relationship between the level of planned behavior in the attitude dimension of hotel employees and their environmental awareness is the most important result obtained from the study data and making the study different. Accordingly, the increase in the amount and level of the effect of environmental interpretations increases the effect of the attitude on environmental awareness more. The most striking example of this situation is seen in the mucilage (sea saliva) event in the Marmara Sea, a current disaster affecting the environment and tourism (The Guardian, 2021). Tourism sector representatives also express their concerns about environmental disaster through the media (Hürriyet, 2021). Therefore, the environmental awareness formed as a result of the attitude of the tourism professionals towards this environmental stimulus event, explains the findings obtained from the research. Accordingly, public and private sector stakeholders in the field of tourism should engage in awareness-raising activities in all groups, especially local people, by using scientific methods against environmental damage. Besides, hotel businesses, NGOs related to hotel management and educational institutions should provide more information about the environment, especially to hotel employees, and encourage them to display protective and control-oriented behaviors towards the environment by increasing their environmental awareness.

There are some limitations regarding this research. The first limitation of the study is that it was carried out in certain months in 2020. Another limitation is that the research only covers five-star resort hotel businesses in Alanya. Accordingly, it can be suggested that similar studies that will be conducted in 


\section{JOURNAL OF TOURISM AND SERVICES}

Issue 23, volume 12, ISSN 1804-5650 (Online)

www.jots.cz

the field of hotel management in the future should be planned at different times and covered different types of hotel businesses (city hotels, mountain hotels, etc.). In addition, it can be recommended to conduct a similar study by associating the variables of this study with different variables. Academicians who carry out their studies in the field of tourism can take these issues into account in the research they plan to do in the future. As a result, all stakeholders operating in the field of hotel management can benefit from the findings and suggestions developed within the frame of this study.

\section{References}

1. Adejoke, O.C., Mji, A. \& Mukhola, M.S. (2014). Students' and teachers' awareness of and attitude towards environmental pollution: a multivariate analysis using biographical variables. Journal of Human Ecology, 45(2), 167-175. https://doi.org/10.1080/09709274.2014.11906690.

2. Ajzen, I. (1991). The theory of planned behavior. Organizational Behavior and Human Decision Processes, 50, 179-211. https://doi.org/10.1016/0749-5978(91)90020-T.

3. Ajzen, I. (2001). Nature and operation of attitudes. Annual Review of Psychology, 52, 27-58. https://doi.org/10.1146/annurev.psych.52.1.27.

4. Ajzen, I. (2002). Perceived behavioral control, self-efficacy, locus of control, and the theory of planned behavior. Journal of Applied Social Psychology, 32, 665-683. https://doi.org/10.1111/i.15591816.2002.tb00236.x.

5. Ajzen, I. \& Fishbein, M. (2005). The influence of attitudes on behavior. Dolores Albarracin, Blair T. Johnson, Mark P. Zanna (Eds.) The Handbook of Attitudes in (pp. 173-221). Lawrence Erlbaum Associates, Publishers, Mahwah, New Jersey.

6. Ajzen, I., \& Madden, T.J. (1986). Prediction of goal-directed behavior: Attitudes, intentions, and perceived behavioral control. Journal of Experimental Social Psychology, 22, 453-474. https://doi.org/10.1016/0022-1031(86)90045-4.

7. Anderson, J. C., \& Gerbing, D. W. (1988). Structural equation modeling in practice: A review and recommended two-step approach. Psychological Bulletin, 103 (3), 411-423. https://doi.org/10.1037/0033-2909.103.3.411.

8. Armitage, C.J. \& Conner, M. (2001). Efficacy of the theory of planned behavior: A meta-analytic review. British Journal of Social Psychology, 40, 417-499. https://doi.org/10.1348/014466601164939.

9. Arnold, J., Loan-Clarke, J., Coombs, C., Wilkinson, A., Park, J. \& Preston, D. (2006). How well can the theory of planned behavior account for occupational intentions? Journal of Vocational Behavior, 69, 374-390. https://doi.org/10.1016/i.jvb.2006.07.006.

10. Arshad, H. M., Saleem, K., Shafi, S., Ahmad, T. \& Kanwal, S. (2021). Environmental awareness, concern, attitude and behavior of university students: A comparison across academic disciplines. Polish Journal of Environmental Studies, 30(1), 561-570. https://doi.org/10.15244/pjoes/122617.

11. Azam, M., Alam, M., \& Hafeez, M. H. (2018). Effect of tourism on environmental pollution: Further evidence from Malaysia, Singapore and Thailand. Journal of Cleaner Produciton, 190, 330338. https://doi.org/10.1016/i.jclepro.2018.04.168.

12. Bagozzi, R. P., \& Yi, Y. (1988). On the evaluation of structural equation models. Journal of the Academy of Marketing Science, 16 (1), 74-94. https://doi.org/10.1007/BF02723327.

13. Ballantyne, R., Packer, J. \& Hughes, K. (2008). Environmental awareness, interests and motives of botanic gardens visitors: Implications for interpretive practice, Tourism Management, 29(3), 439444. https://doi.org/10.1016/i.tourman.2007.05.006.

14. Barron, P. \& Prideaux, B. (1998). Hospitality education in Tanzania: Is there a need to develop environmental awareness? Journal of Sustainable Tourism. 6(3), 224-237. https://doi.org/10.1080/09669589808667313. 


\section{JOURNAL OF TOURISM AND SERVICES}

Issue 23, volume 12, ISSN 1804-5650 (Online)

www.jots.cz

15. Bohdanowicz, P. (2006). Environmental awareness and initiatives in the Swedish and Polish hotel industries survey results. Hospitality Management, 25, 662-682. https://doi.org/10.1016/j.ijhm.2005.06.006.

16. Boiral, O., Guillaumie, L., Heras-Saizarbitoria, I., \& Tayo Tene, C. V. (2018). Adoption and outcomes of ISO 14001: A systematic review. International Journal of Management Reviews, 20(2), 411 432. https://doi.org/10.1111/ijmr.12139.

17. Brown, T. J. Sam H. H. \& Hughes, M. (2010). Picking up litter: an application of theory-based communication to influence tourist behaviour in protected areas, Journal of Sustainable Tourism, 18(7), 879-900, DOI: 10.1080/09669581003721281

18. Buyucek, N., Knox, K., \& Rundle-Thiele, S. (2019). A positive behavioral approach: Identifying theoretical factors influencing moderate drinking practices. Social Marketing Quarterly, 25 (2), 107 122. https://doi.org/10.1177/1524500419830442

19. Byrne, B. (2016). Structual Equation Modeling with Amos, New York: Routledge.

20. Cera, G., Mlouk, A., Cera, E., \& Shumeli, A. (2020). The impact of entrepreneurship education on entrepreneurial intention. A quasi-experimental research design. Journal of Competitiveness, 12(1), 39-56. https://doi.org/10.7441/joc.2020.01.03.

21. Cetin, G. \& Nisanci, S.H. (2010). Enhancing students'environmental awareness. Procedia Social and Behavioral Sciences, 2(2), 1830-1834. https://doi.org/10.1016/i.sbspro.2010.03.993.

22. Chan, E.S.W. (2013). Gap analysis of green hotel marketing. International Journal of Contemporary Hospitality Management, 25(7). 1017-1048. https://doi.org/10.1108/IJCHM-09-2012-0156.

23. Conner, M. \& Armitage, C.J. (1998). Extending the theory of planned behavior: A review and avenues for further research. Journal of Applied Social Psychology, 28(15), 1429-1464. https://doi.org/10.1111/j.1559-1816.1998.tb01685.x.

24. Cortes, A. F., Lee, Y., Cortes, J. D., \& Liñan, I. (2021). Entrepreneurial orientation in supply chain management: A systematic review. International Journal of Entrepreneurial Knowledge, 9(1), 127143. https://doi.org/10.37335/ijek.v9i1.127

25. Culture and Tourism Ministry (2019). Business (Ministry) certified facility accommodation statistics in 2019. https://yigm.ktb.gov.tr/TR-201121/isletme-bakanlik-belgeli-tesis-konaklamaistatistikleri.html, Access date: 17 September 2020.

26. Culture and Tourism Ministry (2020). Businesses with tourism management certificate. https://yigm.ktb.gov.tr/TR-9579/turizm-tesisleri.html Access date: 17 September 2020.

27. Culture and Tourism Ministry (2021). Yatırm ve işletmeler genel müdürlügü̈, turizm işletme belgeli tesisler. https://vigm.ktb.gov.tr/TR-9579/turizm-tesisleri.html (Access Date: 09.06.2021).

28. Du, Y., Wang, X., Brombal, D., Moriggi, A., Sharpley, A. \& Pang, S. (2018). Changes in environmental awareness and its connection to local environmental management in water conservation zones: The case of Beijing, China. Sustainability, 10(6), 2087. https://doi.org/10.3390/su10062087.

29. Evers, A. \& Sieverding, M. (2015). Academic career intention beyond the PhD: Can the theory of planned behavior explain gender differences? Journal of Applied Social Psychology, 45, 158-172. https://doi.org/10.1111/jasp.12285.

30. Fan, Y., Chen, J., Shirkey, G., John, R., Wu, S. R., Park, H., \& Shao, C. (2016). Applications of structural equation modeling (SEM) in ecological studies: an updated review. Ecological Processes, 5 (19), 1-12. https://doi.org/10.1186/s13717-016-0063-3.

31. Fishbein, M. (2004). Intentional Behavior. Charles D. Spielberger (Ed.) Encyclopedia of Applied Psychology, Volume:2 in (pp. 329-334). Elsevier Academic Press Oxford, UK.

32. Fornell, C., \& Larcker, D. F. (1981). Evaluating Structural Equation Models with Unobservable Variables and Measurement Error. Journal of Marketing Research, 18 (1): 39-50. 


\section{JOURNAL OF TOURISM AND SERVICES}

Issue 23, volume 12, ISSN 1804-5650 (Online)

www.jots.cz

33. Gadenne, D.L., Kennedy, J. \& McKeiver, C. (2009). An empirical study of environmental awareness and practices in SMEs. Journal of Business Ethics, 84, 45-63. http://dx.doi.org/10.1007/s10551-008-9672-9.

34. Gavurova, B.; Megyesiova, S. \& Hudak, M. (2021). Green Growth in the OECD Countries: A Multivariate Analytical Approach. Energies, 14, 6719. https://doi.org/10.3390/ en14206719.

35. Goh, E., Ritchie, B. \& Wang, J. (2017). Non-compliance in national parks: An extension of the theory of planned behaviour model with pro-environmental values. Tourism Management, 59, 123127. http://doi.org/10.1016/i.tourman.2016.07.004.

36. Hair, J. F., Black, W. C., Babin, B. J., Anderson, R. E., \& Tatham, R. L. (2005). Multivariate data analysis (6th ed.). New Jersey: Prentice Hall.

37. Hayes, A. F. (2013). Introduction to Mediation, Moderation, and Conditional Process Analysis: A RegressionBased Approach. New York: The Guilford Press.

38. Hrubes, D., Ajzen, I. \& Daigle, J. (2001). Predicting hunting intentions and behavior: An application of the theory of planned behavior. Leisure Sciences, 23, 165-178. https://doi.org/10.1080/014904001316896855.

39. Hu, L. T., \& Bentler, P. M. (1999). Cutoff criteria for fit indexes in covariance structure analysis: Conventional criteria versus new alternatives. Structural Equation Modeling: A Multidisciplinary Journal, 6(1), 1-55.

40. Hürriyet, (2021). Müsilaj Marmara'da etkili oluyor... İste turizmcilerin değerlendirmeleri. https://www.hurriyet.com.tr/ekonomi/musilaj-marmarada-etkili-oluyor-iste-turizmcilerindegerlendirmeleri-41827454 (Access Date: 10.06.2021).

41. Jono, S., \& Ardila, H. (2018). The effect of marketing mix upon the consumer's decision making to buy a product at pt griya pagelaran bogor. The Management Journal of Binaniaga. 3 (1), 59-70. https://doi.org/10.33062/mib.v3i1.241.

42. Lima, E.A., Machado, M. \& Nunes, J.C. (2013). Geotourism development in the Azores archipelago (Portugal) as an environmental awareness tool. Czech Journal of Tourism, 2(2), 126-142. https://doi.org/10.2478/cjot-2013-0007.

43. Littledyke, M. (2008). Science education for environmental awareness: approaches to integrating cognitive and affective domains. Environmental Education Research, 14(1), 1-17. https://doi.org/10.1080/13504620701843301.

44. Mackinnon, A., Jorm, A. F., Christensen, H., Korten, A. E., Jacomb, P. A., \& Rodgers, B. (1999). A short form of the Positive and Negative Affect Schedule: Evaluation of factorial validity and invariance across demographic variables in a community sample. Personality and Individual Differences, 27, 405-416. https://doi.org/10.1016/S0191-8869(98)00251-7.

45. Maibach, E. (1993). Social marketing for the environment: using information campaigns to promote environmental awareness and behavior change, Health Promotion International, 8(3), 209224, https://doi.org/10.1093/heapro/8.3.209.

46. Malhotra N. K., \& Dash, S. (2011). Marketing research: An applied orientation. London: Pearson.

47. Margerum, R. D. \& Born, S. M. (1995). Integrated environmental management: Moving from theory to practice. Journal of Environmental Planning and Management, 38(3), 371-392. https://doi.org/10.1080/09640569512922.

48. Marpa, E.P. (2020). Navigating environmental education practices to promote environmental awareness and education. International Journal on Studies in Education, 2(1), 45-57. https://doi.org/10.46328/ijonse.8.

49. Marsh, H. W., \& Hocevar, D. (1985). Application of confirmatory factor analysis to the study of self-concept: First- and higher order factor models and their invariance across groups. Psychological Bulletin, 97(3), 562-582. 


\section{JOURNAL OF TOURISM AND SERVICES}

Issue 23, volume 12, ISSN 1804-5650 (Online)

www.jots.cz

50. McFarlanc, B. \& Boxall, P. (2003). The role of social psychological and social structural variables in environmental activism: An example of the forest sector. Journal of Environmental Psychology, 23(1), 79-87. https://doi.org/10.1016/S0272-4944(02)00080-4.

51. Mercado, H.U. \& Walker, M. (2012). The value of environmental social responsibility to facility managers: revealing the perceptions and motives for adopting ESR. Journal of Business Ethics, 110, 269-284. https://doi.org/10.1007/s10551-011-1153-x.

52. Miller, D., Merrilees, B. \& Coghlan, A. (2015). Sustainable urban tourism: understanding and developing visitor pro-environmental behaviours, Journal of Sustainable Tourism, 23:1, 26-46. https://doi.org/10.1080/09669582.2014.912219.

53. Nunnally, J. C. (1978). Psychometric theory (2nd edition). New York: McGraw-Hill.

54. Preacher, K. J. \& Hayes, A. F. (2008). Asymptotic and resampling strategies for assessing and comparing indirect effects in multiple mediator models. Behavior Research Methods, 40(3), 879-891. https://doi.org/10.3758/BRM.40.3.879.

55. Ryan, A., \& Spash, C.L., (2008). Measuring Awareness of Environmental Consequences: Two Scales and Two Interpretations. CSIRO Sustainable Ecosystems, Canberra, Australia.

56. Qi, G., Zeng, S., Li, X. \& Tam, C. (2012), Role of internalization process in defining the relationship between ISO 14001 certification and corporate environmental performance. Corporate Social Responsibility Environment Management, 19, 129-140. https://doi.org/10.1002/csr.258.

57. Rustam, A., Wang, Y. \& Zameer, H. (2020). Environmental awareness, firm sustainability exposure and green consumption behaviors, Journal of Cleaner Production, 268, 122016. https://doi.org/10.1016/i.jclepro.2020.122016.

58. Schultz, P.W. \& Zelezny, L.C. (1999). Value as predictors of environmental attitudes: Evidence for consistency across cultures. Journal of Environmental Psychology, 19, 255-265. http://dx.doi.org/10.1006/jevp.1999.0129.

59. Shadfar, S., \& Malekmohammadi, I. (2013). Application of Structural Equation Modeling (SEM) in restructuring state intervention strategies toward paddy production development. International Journal of Academic Research in Business and Social Sciences, 3 (12), 576-618.

60. Shafieisabet, N., \& Haratifard, S. (2020). The empowerment of local tourism stakeholders and their perceived environmental effects for participation in sustainable development of tourism. Journal of Hospitality and Tourism Management, 45, 486-498. https://doi.org/10.1016/i.jhtm.2020.10.007.

61. Sola, A.O. (2014). Environmental education and public awareness. Journal of Educational and Social Research, 4(3), 333-337. http://dx.doi.org/10.5901/jesr.2014.v4n3p333.

62. Sparks, P., Guthrie, C.A. \& Shepherd, R. (1997). The dimensional structure of the perceived behavioral control construct. Journal of Apllied Social Psychology, 27(5), 418-438. https://doi.org/10.1111/i.1559-1816.1997.tb00639.x.

63. Stabler, M.J. \& Goodall, B. (1997). Environmental awareness, action and performance in the Guernsey hospitality sector. Tourism Management, 18(1), 19-33. https://doi.org/10.1016/S0261$\underline{5177(96) 00095-7 .}$

64. Tabachnick, B. G., \& Fidell, L. S. (2007). Using multivariate statistics. Boston, MA: Allyn and Bacon.

65. Tegova, S. (2010). Application of the theory of planned behaviour to career choice: The role of an improved measure of emotion. (Unpublished Honours Thesis). Edith Cowan University, Joondalup, Western Australia.

66. The Guardian, (2021). Turkey struck by 'sea snot' because of global beating. https://www.theguardian.com/environment/2021/may/25/turkey-struck-by-sea-snotbecause-of-global-heating (Access Date: 10.06.2021). 


\section{JOURNAL OF TOURISM AND SERVICES}

Issue 23, volume 12, ISSN 1804-5650 (Online)

www.jots.cz

67. Uslu, A., Alagöz, G. \& Güneş, E. (2020). Socio-cultural, economic, and environmental effects of tourism from the point of view of the local community. Journal of Tourism and Services, 21(11), 1 21. https://doi.org/10.29036/jots.v11i21.147.

68. Wang, C., Zhang, J., Yu, P. \& Hu, H. (2018). The theory of planned behavior as a model for understanding tourists' responsible environmental behaviors: The moderating role of environmental interpretations. Journal of Cleaner Production, 194, 425-434. https://doi.org/10.1016/i.jclepro.2018.05.171.

69. Wohlwill, J.F. (1974). Human adaptation to levels of environmental stimulation, Human Ecology, 2(2), 127-147. https://doi.org/10.1007/BF01558117.

70. Xu, L., Prybutok, V. \& Blankson, C. (2019). An environmental awareness purchasing intention model, Industrial Management \& Data Systems, 119(2), 367-381. https://doi.org/10.1108/IMDS12-2017-0591.

71. Ye, S., Soutar, G.N., Sneddon, J.N. \& Lee, J.A. (2017). Personal values and the theory of planned behaviour: A study of values and holiday trade-offs in young adults. Tourism Management, 62, 107 109. http://doi.org/10.1016/i.tourman.2016.12.023.

72. Yin, H. \& Schmeidler, P.J. (2009). Why do standardized ISO 14001 environmental management systems lead to heterogeneous environmental outcomes? Business Strategy and the Environment, 18, 469-486. https://doi.org/10.1002/bse.629.

73. Zdolsek Draksler, T. \& Sirec, K. (2021). The study of entrepreneurial intentions and entrepreneurial competencies of business vs. non-business students. Journal of Competitiveness, 13(2), 171-188. https://doi.org/10.7441/joc.2021.02.10.

\section{Brief description of Author/Authors:}

\section{Özgür Yayla}

ORCID ID: https://orcid.org/0000-0001-7124-9311

Akdeniz University, Manavgat Tourism Faculty, Department of Recreation Management. Turkey.

Email: ozgur.yayla@akdeniz.edu.tr

Özgür Yayla graduated from Gazi University, Hospitality Management Teaching Department. He completed his master's at Gazi University in Tourism Management Education Department and doctorate degree at Gazi University, in Recreation Management Department. His academic interests are tourism management, recreation management, sustainable tourism, organizational behaviour.

\section{Handan Özçelik Bozkurt}

ORCID ID: https://orcid.org/0000-0002-0035-3362

Sinop University School of Tourism and Hotel Management. Gastronomy and Culinary Arts Department. Turkey.

Email: handanozcelikbozkut@gmail.com

Handan Özçelik Bozkurt graduated from Balıkesir University, Department of Tourism Guiding. She completed her master's at Akdeniz University, and she had a doctorate degree from Hacı Bektaş Veli University, Department of Tourism Management. Her academic interests are hotel management, gastronomy, sustainable tourism, and organizational behaviour.

\section{Emin Arslan}

ORCID ID: https://orcid.org/0000-0003-1592-8162

Tokat Gaziosmanpaşa University, School of Tourism and Hotel Management. Gastronomy and Culinary Arts Department, Turkey.

Email: emin.arslan@gop.edu.tr 
Emin Arslan graduated from Çukurova University, Department of Tourism Management. He completed his master's and doctorate degrees at Gazi University, Department of Tourism Management Education. His academic interests are hotel management, gastronomy, sustainable tourism, and organizational behaviour.

\section{Hakan Kendir}

ORCID ID: https://orcid.org/0000-0002-1356-1339

Tokat Gaziosmanpaşa University, School of Tourism and Hotel Management. Gastronomy and Culinary Arts Department, Turkey.

Email: hakan.kendir@gop.edu.tr

Hakan Kendir graduated from Tokat Gaziosmanpaşa University, Department of Tourism and Hospitality Management. He completed his master's at Tokat Gaziosmanpaşa University, and he had a doctorate degree from Hac1 Bektaş Veli University, Department of Tourism Management. His academic interests are hotel management, gastronomy, sustainable tourism, and organizational behaviour. 
Appendix A.

\begin{tabular}{|c|c|c|c|c|c|}
\hline ITEMS & \multicolumn{3}{|c|}{ Totaly disagree } & \multicolumn{2}{|c|}{ Totaly agree } \\
\hline \multicolumn{6}{|l|}{ Attitude } \\
\hline I think protecting the environment of the scenic spot is wise. & 1 & 2 & 3 & 4 & 5 \\
\hline I think protecting the environment of the scenic spot is good. & 1 & 2 & 3 & 4 & 5 \\
\hline I think protecting the environment of the scenic spot is worthwhile. & 1 & 2 & 3 & 4 & 5 \\
\hline I think protecting the environment of the scenic spot is beneficial. & 1 & 2 & 3 & 4 & 5 \\
\hline \multicolumn{6}{|l|}{ Subjective norm } \\
\hline $\begin{array}{l}\text { Most people who are important to me think I should protect the } \\
\text { environment of the scenic spot. }\end{array}$ & 1 & 2 & 3 & 4 & 5 \\
\hline $\begin{array}{l}\text { People whose opinions I value would want me to protect the } \\
\text { environment of the scenic spot. }\end{array}$ & 1 & 2 & 3 & 4 & 5 \\
\hline $\begin{array}{l}\text { People I am familiar with would protect the environment of the scenic } \\
\text { spot. }\end{array}$ & 1 & 2 & 3 & 4 & 5 \\
\hline \multicolumn{6}{|l|}{ Perceived behavioral control } \\
\hline $\begin{array}{l}\text { I am confident that if I want, I can protect the environment of the scenic } \\
\text { spot. }\end{array}$ & 1 & 2 & 3 & 4 & 5 \\
\hline $\begin{array}{l}\text { Whether or not I protect the environment of the scenic spot is completely } \\
\text { up to me. }\end{array}$ & 1 & 2 & 3 & 4 & 5 \\
\hline It is easy for me to protect the environment of the scenic spot. & 1 & 2 & 3 & 4 & 5 \\
\hline \multicolumn{6}{|l|}{ Environmental Interpretations } \\
\hline $\begin{array}{l}\text { Environmental warning signages in the scenic spot make me regulate my } \\
\text { environmental behaviors consciously. }\end{array}$ & 1 & 2 & 3 & 4 & 5 \\
\hline $\begin{array}{l}\text { Policies such as environmental protection acts of the scenic spot make } \\
\text { me regulate my environmental behaviors consciously. }\end{array}$ & 1 & 2 & 3 & 4 & 5 \\
\hline $\begin{array}{l}\text { Rewards and punitive measures for the environmental protection of the } \\
\text { scenic spot make me regulate my environmental behaviors consciously. }\end{array}$ & 1 & 2 & 3 & 4 & 5 \\
\hline $\begin{array}{l}\text { Environmental persuasive sign ages in the scenic spot make me regulate } \\
\text { my environmental behaviors consciously. }\end{array}$ & 1 & 2 & 3 & 4 & 5 \\
\hline \multicolumn{6}{|l|}{ Environmental awareness } \\
\hline The effects of pollution on public health are worse than we realize. & 1 & 2 & 3 & 4 & 5 \\
\hline Over the next several decades, thousands of species will become extinct. & 1 & 2 & 3 & 4 & 5 \\
\hline $\begin{array}{l}\text { Current environmental pollution has caused the world's climate to } \\
\text { change. }\end{array}$ & 1 & 2 & 3 & 4 & 5 \\
\hline $\begin{array}{l}\text { Environmental protection will provide a better world for me and my } \\
\text { children. }\end{array}$ & 1 & 2 & 3 & 4 & 5 \\
\hline
\end{tabular}

Source: own research 